\title{
Land And Water Management Option of Tidal Lowland Reclamation Area to Support Rice Production (A Case Study in Delta Sugihan Kanan of South Sumatra Indonesia)
}

\author{
Imanudin, M.S. ${ }^{1}$, Bakri ${ }^{1}$, Armanto, $\mathrm{E}^{1}$., Indra, $\mathrm{B}^{2}$ and Ratmini, S.N.P. ${ }^{3}$ \\ ${ }^{1}$ Soil and Water Conservation Laboratory, Department of Soil Science, Faculty of Agriculture, \\ Sriwijaya University, Indonesia \\ ${ }^{2}$ Water Resources Engineering Laboratory, Department of Civil and Environmental Engineering, \\ Bogor Agricultural University, Indonesia \\ ${ }^{3}$ Agricutural Research and Technology, Agricultural Research and Development Council, Ministry of \\ Agriculture, Indonesia
}

\begin{abstract}
The main problem for agriculture at tidal lowland swamp is low soil quality and high acidity of soil and high water. The research objective was to investigate how far the effort in increasing tertiary canal network to improve water quality (increasing $\mathrm{pH}$ and reducinf iron) in channel and tertiary plot. Field study was conducted at Bandarjaya Village of Jalur 25, Delta Sugihan Kanan, South Sumatra. Field activities were consisted of network investigation land use and farm enterprise system which located at Primr 13 of Sugihan Kiri and Primer 25 of Sugihan Kanan. The network improvement perfomance was conducted by constructing micro water management (installed the tertiary gate and developen quartey canal) at tertiary plot which consisted of collector channel, sub tertiary channel and control plot which was outfall at quarterly channel downstream end. Water gate having goose neck pipe system was constructed to control water table in tertiary channel. Results of field study showed that land use at the study area was still dominated by rice crop with magnitude of $83 \%$ and the rest of $17 \%$ was used for rubber plantation, orange planation and mix plantation. The depth of phyrite layer was in the range of 60 to $100 \mathrm{~cm}$ below soil surface. Water table surface in October was in the range of 10 to $35 \mathrm{~cm}$. Field adaptation showed that water gate was operated in closed condition (water retention) during vegetative phase. Water retention showed significant to improve rice yield in which water table since November had increased from $-10 \mathrm{~cm}$ to flooding condition of $15 \mathrm{~cm}$ in January. This condition provide sufficient water for rice crop which was similar as the result found at irrigation area. The addition of ameliorant substances such as coconut fiber, and sand semen block at outfall of tertiary and kuartely channels also increase water quality in which water $\mathrm{pH}$ was increased from 2.95 to 3.7 and iron concentration was decreased from 4.01 to $0.32 \mathrm{mg} / \mathrm{liter}$. Rice yield was increased from average production of 2 ton/ha to 3 ton/ha. This low production was due to land flushing process which need longer time process for at least 2 to 3 years from current condition as well as other production inputs such as fertilization and ameliorant substances.
\end{abstract}

Key words: tertiary network, rice, tidal lowland swamp, sugihan

\section{INTRODUCTION}

The need for rice commodity was increasing from year to year due to population increase in Indonesia. The increase of population should be compensated by increasing rice production because rice is staple food for Indonesia people. On the other hand, irrigation land

Correspondence Author: Momon Sodik Imanudin. Soil and Water Conservation Laboratory, Department of Soil Science, Faculty of Agriculture, Sriwijaya University, Indonesia, Email: momon_unsri@yahoo.co.id

Journal of Wetlands Environmental Management Vol 6, No 2 (2018) 93 - 111 http://dx.doi.org/10.20527/jwem.v6i2.165 area at Jawa, Bali and Madura islands were decreasing due to the change of land use from agricultural usage into non-agricultural usage (industry, settlement, structure and infrastructure as well as recreation) which can achieve 40,000 ha per year (Susanto, 2007). This change of agricultrural land use should be compensated by maximizing swamp land utilization, especially swamp land available at outside of Java island. Indonesia had 2.07 millions ha of potential land, 6.70 millions ha of acid sulphate land, 10.89 millions ha of peat land and 0.44 
millions ha of saline land based on land typology (Nugroho et al., 1993; Suriadikarta and Sutriadi, 2007).

Agricultural Food Security Agency (FSA) of Indonesia in 2017 had reported that Indonesia government will increase domestic rice production target from 72 million tons in 2016 into 77 million tons in 2017. Indonesia government will not import rice due to 5 millions ton increase of rice production. The production increase from previous years requires proper strategy, expansion program for planting area with new paddy field development or increasing the planting itensity into two times per year for the existing paddy field. South Sumatra is one of mainstay province in supporting national rice production. It had extensive area for rice cultivation especially with the land clearing of tidal lowland swamp since 1969. There was currently about 370,000 ha of tidal lowland swamp that had been opened for food agriculture, but only $20 \%$ of this area that implemented two times planting (LWMTL, 2006). If two times planting can be done with average rice production of 3 ton/ha, then there will be rice production increase with magnitude of 1.1 million tons. This condition was fulfilled merely from tidal lowland swamp area. Therefore, the proper policy is by increasing the planting time into two times for the currently opened land. In addition, production for first planting season should be increased from average of 3 ton/ha to 5 ton $/$ ha. Areas that should be developed in term of rice production and planting intensity are delta Sugihan Kiri at Banyuasin District and Sugihan Kanan at Ogan Komering Ilir District. Average rice production in these areas was only 2.5 ton/ha with one time planting (Imanudin at al., 2017). By application of proper water management, average rice production at tidal lowland swamp could achieved 5-6 ton/ha such as found at delta Telang I and II (Imanudin et al., 2010; Imanudin and Bakri, 2014). Therefore, the field study is still needed to investigate current condition of land and water management which in turn can be constructed as improvement recommendation. According to Imanudin and Bakri (2014), the problem of farm enterprise at swamp area was due to water status condition. Water is frequently not available in proper quantity, quality and site according to crop water requirement. Improper condition of drainage system results in under optimum of toxic substances flushing process which subsequently accumulated within roots zone. Therefore, the key point is water management effort at micro and macro levels of tidal lowland. In addition, according to Meijide et al. (2017), water table drawdown can increase carbon release rate. Proper water management for rice crop with an objective to increase soil water surface can decrease carbon release rate. Reported by Kima et al., (2014), that maintenance water depth at $3 \mathrm{~cm}$ is produce high yield of rice and promotes good water quality by increasing $\mathrm{pH}$ and lowering iron content in the root zone.

The study results by Imanudin and Armanto (2012) showed that water status diversity was affected by land hydrotopography, rainfall and high tide water potential. Every areas have different conditions so that they have different objective in term of water managment (Imanudin and Susanto, 2015). Water table depth is also highly depended on the existing drainage system, rainfall input, crop growing stage and water gate operation (Mercau et al., 2016). Zimmermann et al. (2017) had mentioned that contribution from capillary water movement was very important to fulfill crop water requirement and its magnitude is highly depended on position of water table depth. The above condition requires different objective in term of water management. The current mistake problemis applying similar option of water management and even water table control structures. Therefore, water management objective can not be achieved and resulting in improper function of water structures. This paper will present results of study and 
field application in term of perfomance improvement efforts for tertiary network through development of micro water management at farm area and development of water table control structures. Development was conducted by involving farmers through participative approach. Some advantages can be achieved through this approach such as low cost of structures and farmers can build proper structures because they have sense of belonging. This pattern should be developed in the near future.

\section{METHODOLOGY}

Field study to investigate problems of farm enterprise and water management system was conducted at Beringin Agung Village Primer 13 Sugihan Kiri of Banyuasin District and Bandar Jaya Village Jalur 25 Sugihan Kanan of Ogan Komering Ilir District. Field expriment in term of micro water management improvement was conducted at Tersier 4 plot located at Bandar Jaya Village Jalur 25 Air Sugihan of Ogan Komering Ilir District, South Sumatra. This study was conducted from September 2016 to February 2017.

Materials used in this study were construction materials for water gate development which consisted of sand, cement, paralon pipe, elbow, steel, bamboo, gelam wood, brick and wooden board. Equipments were consisted of water vessel, carpentry tools and hoe. Survey was done by using questioner materials and administratitive equipments.

\section{The activity phases were as follows:}

Activities in first phase were directed to obtain initial condition of network system, water structure facility, water quality and land use. Focused discussion with farmers community was also conducted in these activties to explore information related to farm enterprise as well as problems related to water and soil quality in crop cultivation effort. Data was also obtained through direct interview with farm land owners/managers at tertiary plot in term of farm enterprise opportunity for second planting after rice crop.

The second phase was field expriment. This activity was conducted to compose recommendation for water management improvement according to field condition and farmers role. The improvement design for water managment network was consisted of :

- Collector channel development (the location is border on secondary channel embankment);

- Sub-tertiary channel development which border on tertiary channel;

- Quarterly channel development (as land ownership border) and to carry water during high tide water period from tertiary channel as well as to drain product of land leaching into tertiary channel;

- Box control development at outfall of quarterly channel, and

- Tertiary water gate development at outfall which was directly related into secondary channel.

Illustration of water structure design in tertiary channel can be seen in Figure 1. The different in water surface height will be controlled by height of goose neck pipe. There was minimum limit of water height that should be retained in tertiary channel. Tertiary channel has function as water storage (long storage) so that water table depth was not quickly dropped. There was mud settling pond in inner section (downstream) before entering tertiary channel in which its base equipped with conblock (ameliorant); water plants were planted at water surface that capable to increase $\mathrm{pH}$ of water and decrease iron concentration. These water plants were bordered with float to prevent them from flowing due to water current (Figure 2) 


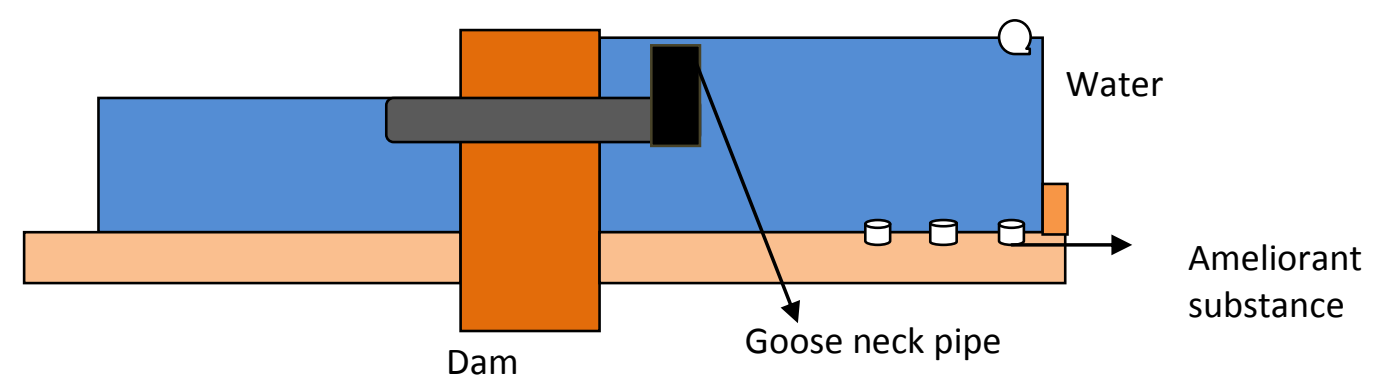

Figure 1. Hydraulic construction of water structure at tertiary channel has function as water retention (maximizing rainfall water storage).

Water retention test at tertiary level was conducted after the development of water management system. Daily water surface monitoring was subsequently be conducted as success indicator of water network. Water availbility in land is success indicator of the system in providing water for rice crop. The retained water was rainfall water which have good quality.

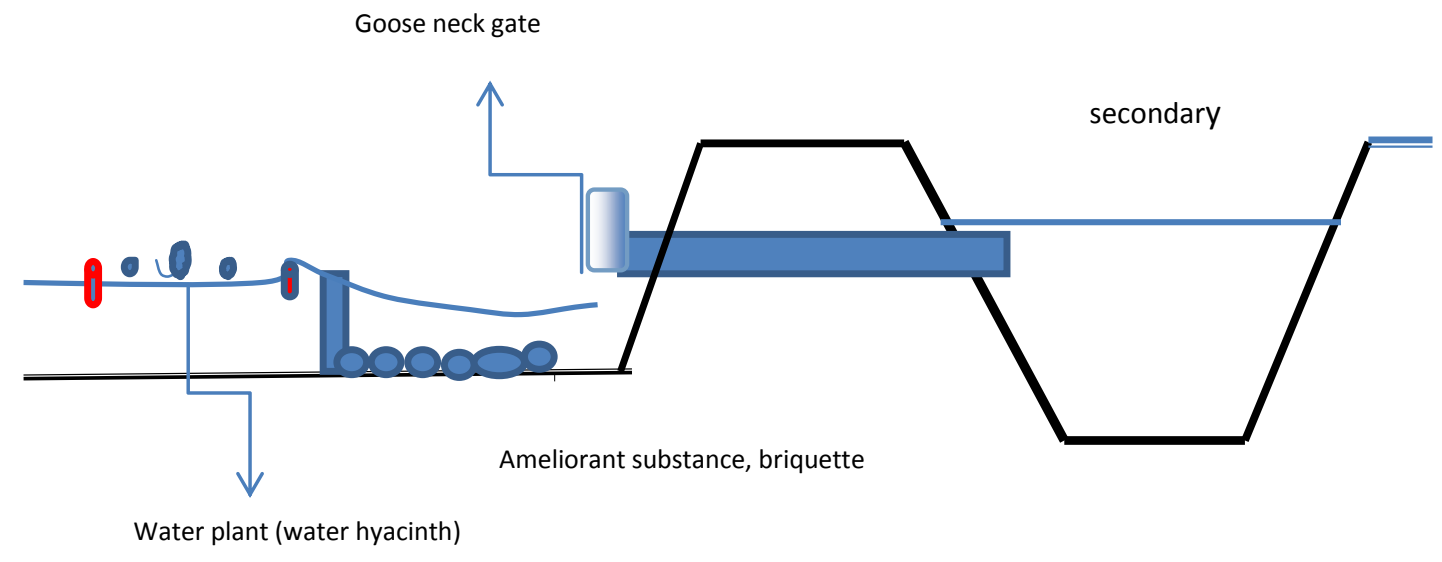

Figure 2. Cross section of water flow and purification system in secondary channel

\section{RESULTS AND DISCUSSION}

\section{General Description of Primer 13 Sugihan Kiri}

Agriculture at Beringin Agung Village P13 Sugihan Kiri was located within area of Banyuasin District. Land use was dominated by rice crop with magnitude of $80 \%$ and the rest was mix plantation (coconut, perennial trees, rubber and oil palm).

Condition of water management system in this area was pair comb system in which tertiary channels was not connected into secondary channel. One side of tertiary channel was connected into Village Supply Channel (SPD), whereas the other side was not connected into secondary channel as the main drainage. The channel which connected into Main Drainage Secondary Channel was also not connected into Village Supply Channel (SPD). Condition of the unconnected tertiary channel can be seen in Figure $3 \mathrm{a}$, whereas the connected tertiary channel can be seen in Figure $3 b$. 


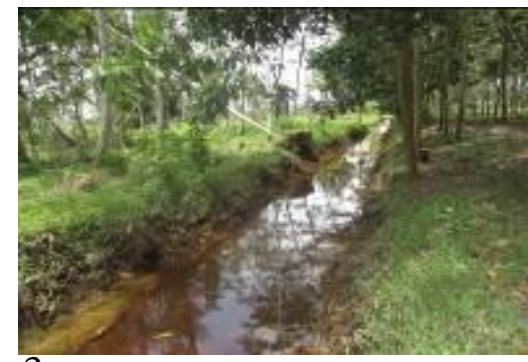

$3 \mathrm{a}$

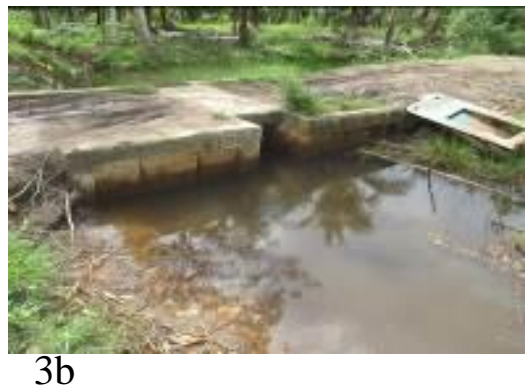

$3 \mathrm{~b}$

Figure 3. Tertiary channel condition at reclaimed area of Sugihan Kiri, Primer 13 Banyuasin

Water gate nowadays was installed at village road (Figure 4). This road was used for transportation of agricultural machinery and equipment as well as for transportation of four wheel vehicles to carry agricultural products. Water gate construction is improper because it was too small in size and probably will be damaged. In addition, the installed valve water gate was no longer used by farmers. This water gate was shown in Figure 4. Water gate construction should be better developed by using box culvert.

Current condition of farm enterprise should be improved because land was only cultivated one time using rice crop with low average production with magnitude of 2.5 ton/ha. Some land locations had peat depth in the range of 30 to $50 \mathrm{~cm}$. Soil maturity process was still low because of poor drainage system. Drainage process especially during wet season was not function properly because most of secondary channels were shallow due to sedimentation resulting in very low water flow pattern (Figure 4). On the other hand, channels were dominated by the growth of water grasses. Therfore, preliminary improvement for water management system was needed and agricultural program should be conducted together with program from Public Work Ministry. Agricultural inputs should be given on area that had already have good water management network at macro and micro levels.

Evaluation on program of agricultural production cost input with magnitude of Rp. 3,000,000/ha given by Agricultural Ministry showed that it was unsuccessful. The given production input was improper because of poor physical land condition. The initial step should be conducted by improving physical land condition through improvement of macro and micro water networks. Improvement of macro water network was important as the main drainage to flush toxic substances from tertiary channel due to land flushing process. Improvement of micro water network is important by developing water management at land plot (Micro Water Management), sub-tertiary channel and collector channel surrounding land to drain acid substance that accumulated at cultivated land. After channel flushing, channel should retain rainfall water as maximum as possible so that water table was not quickly dropped and land can store rainfall water during wet season. The concept used in this area was to retain rainfall water as maximum as possible. Water pumping from outside area was not allowed because high tidal water had low quality, containing acid substance during wet season or middle season as well as frequently had high salinity during dry season. At least two years was required to flush the land from acid substance and heavy metals. After micro water management was properly developed, then liming application at initial stage is required to improve soil fertility. In addition, there was no water gate in secondary channel. This water gate is important at least to retain salt water intrusion during dry season and to retain rainfall water as maximum as possible approaching the end of wet season. 


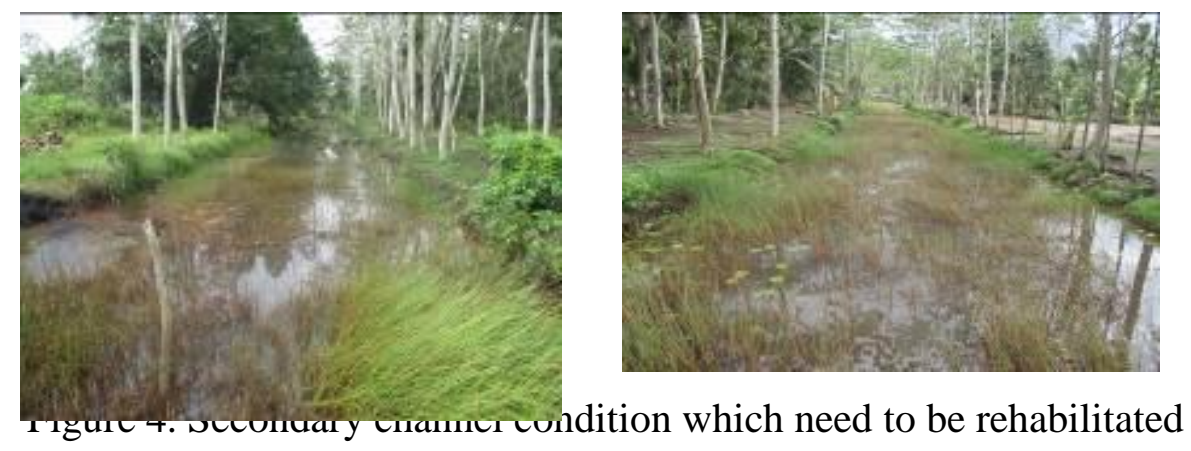

\section{General Description of Farm Enterprise Condition and Water Management at Bandar Jaya Village Jalur 25 Air Sugihan Kanan, Ogan Komering Ilir District}

Areal condition at Bandar Jaya Village had already showed land functional shifting such as indicated by farmers complaint in term of low soil fertility and unpredictable condtion of season. Functional shifting from agricultural land into oil palm plantation covering area of 38 ha, rubber plantation of 38 ha and coconut plantation of 3 ha had occurred at the east block of Bandar Jaya Village. Intercropping method was also conducted by some farmers by adding perennial trees at paddy field ridge such as oil palm-rice of 11 ha, coconut-rice of 9 ha, rubber-rice of 6 ha and orange - rice of 6 ha, respectively.

This land functional shifting had been increased yearly resulting in the decrease of paddy field land as the producer of main food. Although area of paddy field land was still dominate in term of percentage (Figure 5) with magnitude of $83 \%$ from total land available at the east block, but this land functional shifting had potential to decrease area of paddy field land at Bandar Jaya Village so that immediate action should be taken.

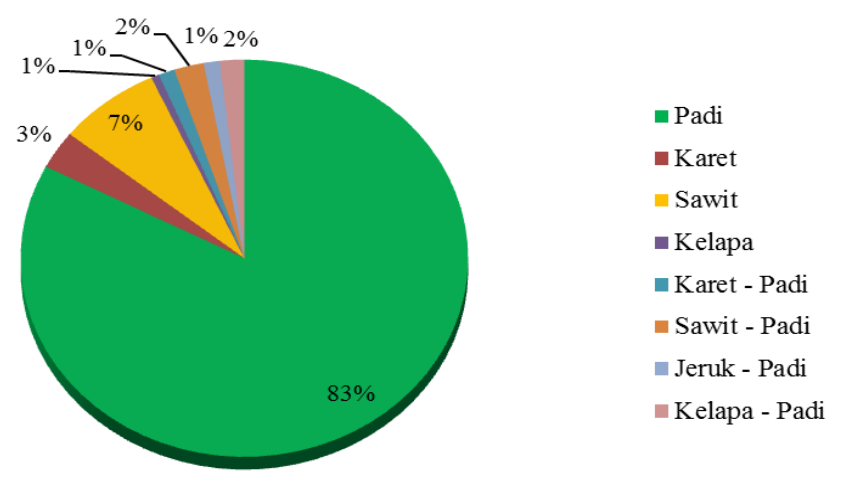

Figure 5. Land use percentage at East Block of Bandar Jaya Village at First Planting Season in 2016

Source: Intreview results with head of farmer groups at Bandar Jaya Village

Observation on water quality in tertiary channel showed that it can be categorized as acid with $\mathrm{pH}$ of 3 and water quality in flooded water pond showed very acid level with $\mathrm{pH}$ of 2.5 . This water acidity was originated from phyrite oxidation process at dry season which produce acid. Field Journal of Wetlands Environmental Management Vol 6, No 2 (2018) 93 - 111 http://dx.doi.org/10.20527/jwem.v6i2.165 observation showed that phyrite layer depth was in the range of 80 to $90 \mathrm{~cm}$. Water table depth during this observation was $45 \mathrm{~cm}$ below soil surface.

Rice seeds planting was conducted in October by using method of direct seeds spreading. It requires high quantity of seeds 
with magnitude of $90 \mathrm{~kg}$ (18 sacks having weight of $5 \mathrm{~kg} / \mathrm{sack}$ ) to plant 1 ha of rice crop. Rice varities commonly used were IR 64, Ciherang, Ciliwung and PB. Upkeeep to maintain soil fertility was conducted by using fertilizers as follows: Urea dose of 200 $\mathrm{kg} / \mathrm{ha}$; Super Phospat 36 dose of $100 \mathrm{~kg} / \mathrm{ha}$ and Phonska (Nitrogen fertilizers) dose of $200 \mathrm{~kg} / \mathrm{ha}$. Harvest yield per hectare was in the range of 60 to 80 sacks ( $50 \mathrm{~kg}$ per sack). The selling price of unhulled rice during harvest period was in the range of 7,000 to 8,000 rupiahs.

In general, there was three main problems of land that can be identified at the study location as follows: a) Water Management and Water Quality, b) Soil Fertility and 3) Crop Pest and Disease.

Water dynamics condition was observed for 24 hours. Water surface fluctuation per hour in channels and water table on land was observed every hour such as shown in Figure 8. This figure clearly showed that water surface in tertiary channel follows water surface pattern in secondary channel with no retention process of high tidal water and water gate was opened to facilitate water inflow and outflow. The main objective during October was to maximize land leaching process and to drain acid substances in channels (flushing). Water table surface was within roots zone as an impact from water inflow in tertiary channel. Soil water was located at maximum of $-21 \mathrm{~cm}$ and it was located near soil surface $(0 \mathrm{~cm})$ during high tide water period (Figure 6). Process of water surface drawdown (low tide period) was occurred in relatively long period from $03.00 \mathrm{pm}$ to 18.00 am or 16 hours. Water surface drawdown tend to be followed by drawdown in tertiary channel in which peak of water surface at $70 \mathrm{~cm}$ progressively dropped to the lowest point of $30 \mathrm{~cm}$ within 15 hours period and then it was increased again. Water table was at 18 to $20 \mathrm{~cm}$ below soil surface when water surface in tertiary channel was at 30 to $40 \mathrm{~cm}$. This condition showed that if tertiary channel regularly receive water supply, then water table would dropped below phyrite layer.

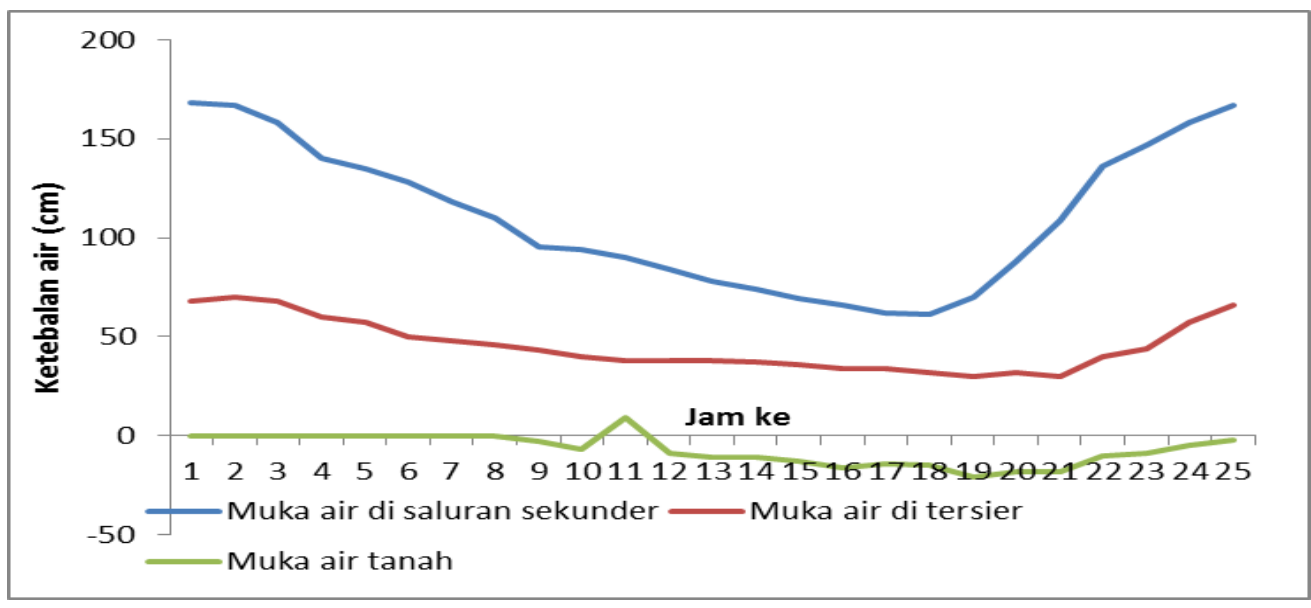

Figure 6. Hourly water table dynamics at channel and land plot

\section{Perfomance Improvement of Water Management Network}

Tidal lowland swamp area of Delta Sugihan Kanan Jalur 25 which located at Bandar Jaya Village was classified as B hydrotography class as well as close to $\mathrm{C}$ hydrotography class. This condition was Journal of Wetlands Environmental Management Vol 6, No 2 (2018) 93 - 111 http://dx.doi.org/10.20527/jwem.v6i2.165 characterized by high tidal water that incapable to flood the land so that there was no potential of high tidal water irrigation through gravitation. Water was only flow into tertiary channel. Water table condition was $0 \mathrm{~cm}$ during high rainfall period and it was in the range of 30 to $40 \mathrm{~cm}$ below soil 
surface in October period. However, soil was still moist at upper part of soil surface.

Rice growth condition at tertiary plot was diverse because farmers had done planting at different times. Some farmers had done

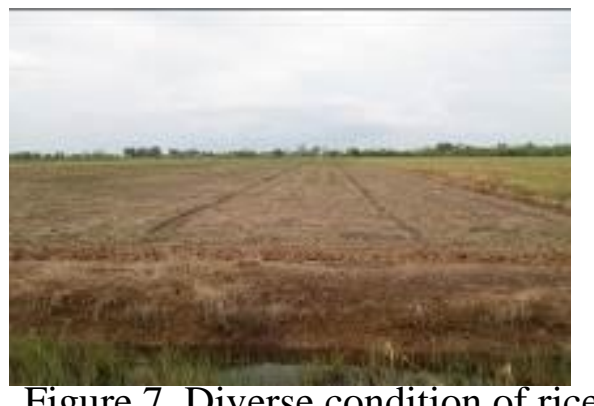

Micro water management was built at tertiary plot in order to accelerate acid substances leaching in land. This micro water management was consisted of collector channel, sub-teriary channel and quarterly

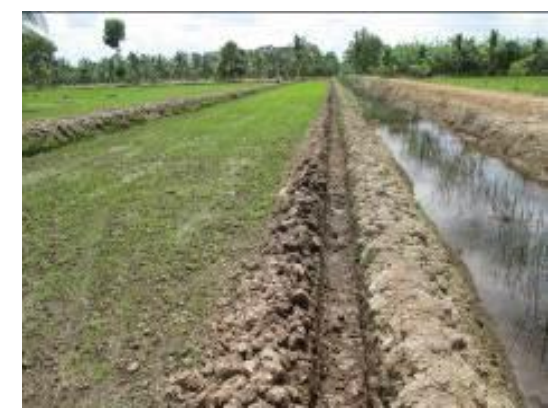

seeds spreading, some seeds had been grown having age of 14 days and some land had not been tilled yet. Description of land condition can be seen in Figure 7.

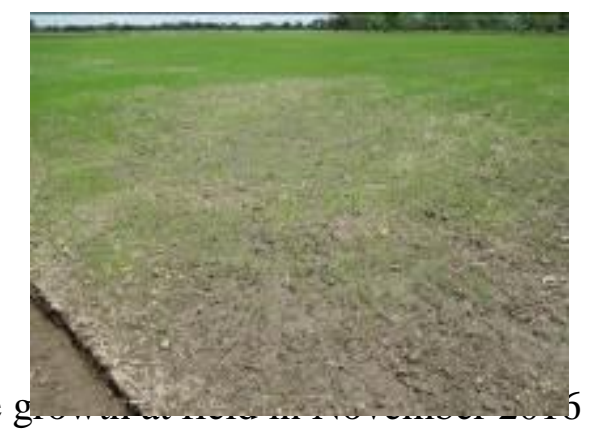

channel. In addition, farmers are asked to make very small channel (worm channel) with distance of $8 \mathrm{~m}$ for every channel and as wide as a hoe. Description of micro water management can be seen in Figure 8.

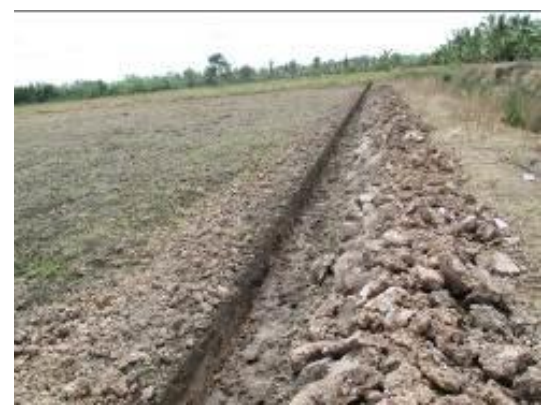

Figure 8. Micro water management at tertiary block of tidal lowland reclamation areas

The land was classified as rain fed land based on flooding type characteristics and water table condition in which availability of rainfall water was very important for crop evapotranspiration and land leaching. Water management concept is how farmers capable to maximize rainfall water (rainfall harvesting) so that rainfall water was not quickly drained into tertiary channel and toward secondary channel. Therefore, the main option for water management objective was water retention concept. Tertiary channel has function as rainfall storage pond (long storage) in order to maintain shallow water table depth at teriary plot within $30 \mathrm{~cm}$ zone below soil surface (Imanudin et al.,
2011). Land was potential to be flooded at least at puddling condition during rainfall occurrence and water can be retained for several days as well as not directly drained into channel. This condition was required because rice crop needs constant wet soil condition in order to depress weeds growth and water stress would be occurred if water table was dropped at $20 \mathrm{~cm}$ depth for more than 3 days.

Field study showed that valve water gate was not suitable for water retention option. Therefore, model of water table control was done by using water structure that capable to retain rainfall water and can be opened for drainage operation. This controlled model 
can be fulfilled by using system of goose neck pipe. Two paralon pipes having diameter of 12 inches were installed within tertiary structure. Process of water gate making from preparation stage to development stage can be seen in Figure 9. The operational principle of this system was very simple in which excess of rainfall water (surface flow from land) would flow into tertiary channel. Water was held previously in box control before flowing into tertiary channel. Rainfall water can be stored as maximum as possible in tertiary channel so that tertiary water gate was in permanently closed condition. In order to prevent leakage, culvert structure was installed using concrete protector. Elbow (L) was installed and was connected with pipe which resembles goose neck on outside pipe toward inside part (Figure 9). Water can not outflow from tertiary channel into secondary channel due to condition of goose neck pipe. If rice crops need no water or flushing operation will be conducted in tertiary channel, then goose neck pipe was removed and water will be drained into secondary channel during low tide water. Goose neck pipe was operated at installed condition which indicate that it was used to retain rainfall water (rain harvesting).

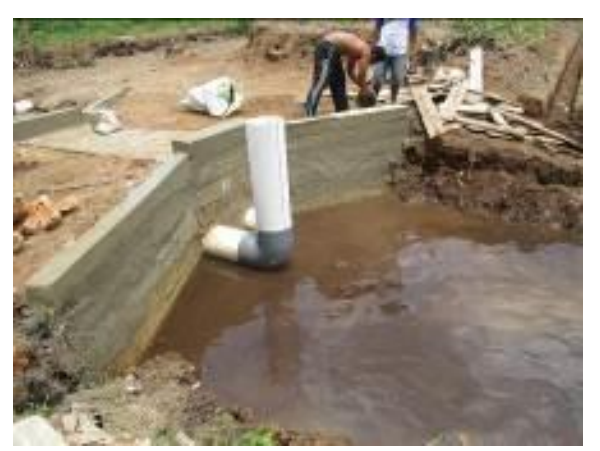

Figur 9. Operation of goose neck-type water gate to retain water

Operation of water structure by using water retention concept results in low water quality in channel. Iron concentration was increased and soil acidity was decreased. Meanwhile, water flushing operation from channel would results in empty channel, water supply from rainfall is insufficient and water table would quickly drop that can oxidize phyrite layer. Phyrite layer at the study area was vary from shallow to relatively deep with magnitude of 60 to 90 $\mathrm{cm}$ below soil surface. Therefore, water management was conducted by using passive technique. Water management from channel base was conducted by immersing ameliorant conblock and coconut sabut. Additive substance in form of rice straw ash was also added. It is expected that addition of conditioner substances into channel mud would capable to increase activity of soil microbia within water which subsequently can increase soil $\mathrm{pH}$. Soil conditioner in form of briquette made from cement, sand and rice straw ash had been tested at laboratory and it was capable to increase water $\mathrm{pH}$ from 2 to 6.7 . Field test was conducted at area of tertiary canal outfall. This ameliorant conblock had slow release characterstics resulting in gradual increase of $\mathrm{pH}$. Phytoremediation method was also conducted to purify surface water quality. Water plants used in this method were water hyacinth and lotus.

\section{Water Quality Improvement at Teriary Level}

The study area had phyrite depth at $90 \mathrm{~cm}$ below soil surface so that no phyrite oxidation was occurred during 2016 because water table depth was $50 \mathrm{~cm}$ below soil surface during observation at dry season period of October. However, the effect of dry season in 2015 had produced acid substance 
accumulation in roots zone of crop that was not maximally leached. This condition results in low water quality. Byproducts result from phyrite oxidation had produced acid substances that were drained into tertiary channel or water body. Therefore, water purification was needed before it was drained or before it was entered into land through high tide water. The study of water table status in the field showed that it was located at 45 to $50 \mathrm{~cm}$ below soil surface. This condition was very suitable for corn growth. The evapotranspiration requirement can be fulfilled by capillary soil water movement at this water table depth (Imanudin and Bakri, 2014). Although surface water in channel showed low $\mathrm{pH}$ of 3 , but it was not toxic to crop because land was not flooded by this water. Therefore, water management system on land and box control at outfall of quarterly channel were required in order to prevent the effect of poor quality of surface water (Figures 10-11). This system could passively produce water purification through application of additive substances in box control. Therefore, water previously reacts with ameliorant substance before entering quarterly channel which in turn could increase soil $\mathrm{pH}$. On the other hand, drained water from land was also previously flow into box control so that acidity and solubility of toxic substances were decrease before flowing into tertiary channel. Water flow into tertiary channel was connected with 5 inch pipe.

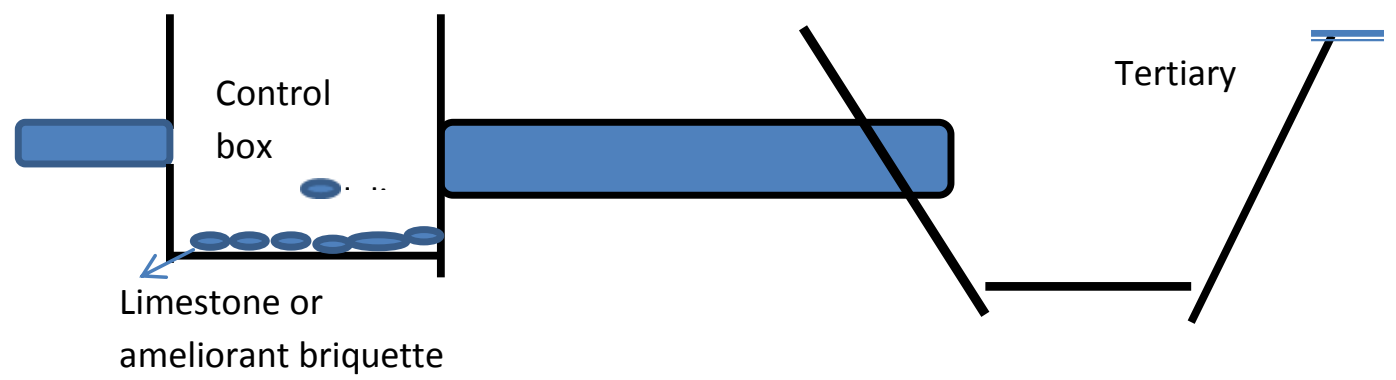

Figure 10. Cross section of water flow system from tertiary channel into quarterly channel
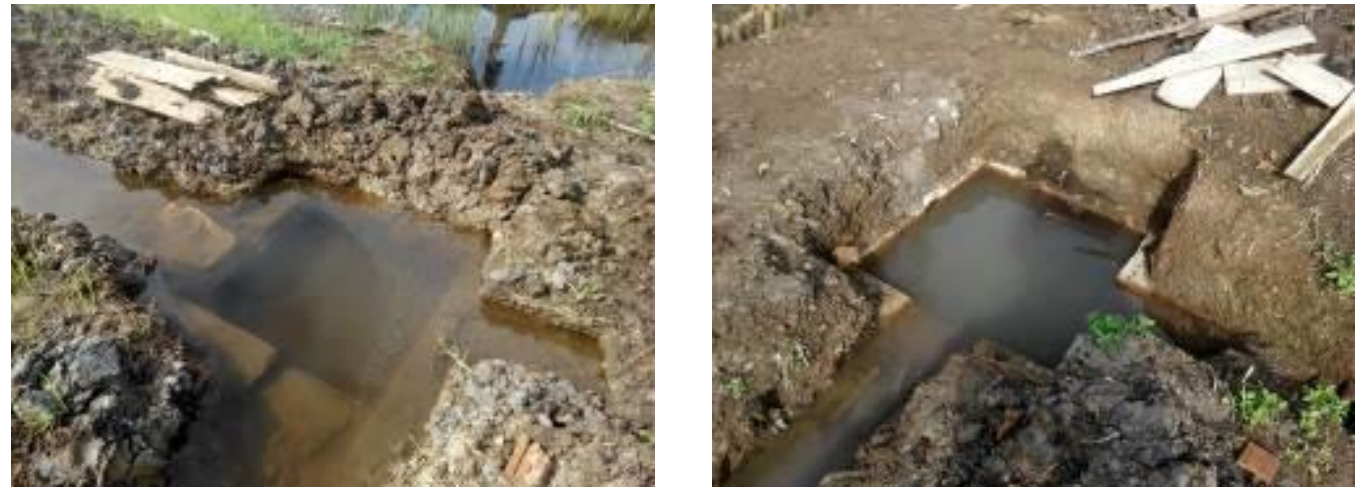

Figure 15. Condition of control box at outfall of tertiary channel

Water quality in channel was very poor and it was not suitable to be used as irrigation water source. Water sampling was conducted two times in October and November 2016 for laboratory test. Analysis results showed that $\mathrm{pH}$ of water was very acid in the range of 2.9 to 3.0 (Table 1). This
$\mathrm{pH}$ condition was very vulnerable for crops. In addition, water was also contain relatively high concentration of iron. This acid water condition facilitate Fe solubility so that acid water usually has high $\mathrm{Fe}$ concentration. However, analysis results at this time showed low $\mathrm{Fe}$ concentration so that this 
water had fulfilled the criteria as irrigation water standard. This was in accordance to the study result by Yusuf (2014) which stated that $\mathrm{Fe}$ concentration in water can be considered suitable for irrigation water if its concentration in water was less than 10 $\mathrm{mg} / \mathrm{liter}$. Low concentration of $\mathrm{Fe}$ was probably due to rainfall during OctoberNovember period. However, $\mathrm{Fe}$ concentration higher than $1 \mathrm{mg} / \mathrm{L}$ was considered dangerous for aquatic organisms life (Moore, 1991). In addition, poor water quality was also shown by sulphate concentration in water which exceed tolerant threshold limit. According to Scofield (1936), water is not suitable for irigation if its sulphate concentration is higher than 20 $\mathrm{mg} / \mathrm{liter}$, whereas Yusuf (2014) had stated that water was suitable for irrigation if its sulphate concentration is less than $7 \mathrm{mg} /$ liter.

Table 1. Analysis results of water quality from channels at tidal lowland area of Jalur 25 of Sugihan Kanan

\begin{tabular}{llll}
\hline \multirow{2}{*}{ No. } & \multicolumn{1}{c}{ Parameters } & \multicolumn{2}{c}{ Dates of sample taking } \\
\cline { 3 - 4 } & & 20 October 2016 & 2 November 2016 \\
\hline 01 & Acidity level $(\mathrm{pH})$ & 2.92 & 3.00 \\
02 & $\begin{array}{l}\text { Iron concentration }(\mathrm{Fe}) \\
(\mathrm{mg} / \mathrm{l})\end{array}$ & 3.61 & 11.51 \\
03 & $\begin{array}{l}\text { Sulphate concentration } \\
(\mathrm{mg} / \mathrm{l})\end{array}$ & 27.33 & 57.50 \\
\hline
\end{tabular}

Simple treatment had been done in laboratory in order to decrease iron and sulphate concentrations as well as to increase $\mathrm{pH}$ of water. This test was conducted by addition of substances that had additive characteristics. Treatment was consisted of addition of rice straw ash and conblock plus made of sand, cement, lime and rice straw ash. Phytoremediation method was also tested by planting of water hyacinth. Analysis results of ameliorant substances addition for one week period showed significant effect in decreasing iron concentration and in increasing $\mathrm{pH}$ of water (Table 2). Addition of rice straw ash was capable to increase $\mathrm{pH}$ to 7.5 and to decrease iron concentration to $0.05 \mathrm{mg} / \mathrm{liter}$. The best result from conblock plus treatment had produced alkaline $\mathrm{pH}$ and had decreased iron concentration. Increase of water $\mathrm{pH}$ in conblock treatment showed relatively high neutralizing power of conblock so that dose of 1:4 volume ratio (1 part of conblock and 4 liters of water) was too high. Therefore, treatment series were needed to obtain the optimum dose. Treatment of water hyacinth was also effective in decreasing iron concentration and in increasing $\mathrm{pH}$ of water. However, all treatments were incapable to decrease sulphate concentration in water 
Table 2. Laboratory analysis results related to treatment effect on water channel purification

\begin{tabular}{llccc}
\hline No. & Parameters & \multicolumn{2}{c}{ Dose treatment 1:4 unit of volume } \\
& & Rice straw ash & $\begin{array}{c}\text { Water } \\
\text { hyacinth }\end{array}$ & Conblock Plus \\
\hline 01 & Acidity level $(\mathrm{pH})$ & 7.54 & 5.96 & 9.18 \\
02 & $\begin{array}{l}\text { Iron concentration }(\mathrm{Fe}) \\
\text { (mg/l) }\end{array}$ & 0.05 & 0.16 & 0.3 \\
03 & $\begin{array}{l}\text { Sulphate concentration } \\
(\mathrm{mg} / \mathrm{l})\end{array}$ & 83.18 & 38.74 & 57.35 \\
\hline
\end{tabular}

Note: Incubation for duration of 10 days

\section{Study of Water Quality Change in Field}

Environmental condition especially drainage water was very acid at condition of acid soil. This was shown by $\mathrm{pH}$ of water less than 3 found in tertiary channel. Acid soil condition causes the increase of iron and alluminum solubilities. This would highly depress other nutrients availability, especially phosphorus at certain condition (Panhwar et al., 2016). Therefore, improvement of soil quality and water quality should be done at initial stage in order to increase $\mathrm{pH}$ value.

Water sampling in tertiary and secondary channels was done to determine the change of water quality as impact from addition of ameliorant substances. Processing effort in the field was done by addition of synthetic additive substances in form of conblock (mixing of cement, rice straw ash and lime) at tertiary channel outfall and water was previously flown into treatment pond at box control before entering into quarterly channel. Analysis results showed relatively significant change of water quality in quarterly channel. The increase of $\mathrm{pH}$ was only one digit so that it needs to be increased at leat to $\mathrm{pH}$ of 5 . However, $\mathrm{pH}$ of water in the field was relatively good with magnitude of 5 as indicated by $\mathrm{pH}$ paper test. Oxidation was probably occurred during analysis at laboratory. Significant decrease of iron concentration was found in tertiary channel water with magnitude of $4 \mathrm{mg} / \mathrm{liter}$, whereas iron concentration in treatment pond was decreased to $0.32 \mathrm{mg} /$ liter and it was very suitable for irrigation. The decrease was also found on sulphate concentration from 29.9 $\mathrm{mg} / \mathrm{liter}$ to $6.8 \mathrm{mg} / \mathrm{liter}$ which was suitable for irrigation water requirement.

The decrease of iron concentration (Table 3) at quarterly channel level showed positive result because this water will be directly used to irrigate crops at tertiary plot. Iron toxicity was frequently found on rice cultivation at tidal swamp land (Sebastian, A. and Prasad, 2015). Iron toxicity on rice was due to high concentration of $\mathrm{Fe}$ in soil or within soil solution. Study results showed that $\mathrm{Fe}$ concentration in soil solution which cause Fe toxicity on crops were highly vary. Critical limit of $\mathrm{Fe}$ concentration in soil solution which cause iron toxicity was in the range of $100 \mathrm{ppm}$ at $\mathrm{pH}$ of 3.7 and $300 \mathrm{ppm}$ or higher at $\mathrm{pH}$ of 5.0 (Sahrawat et al., 1995). According to Asch et al. (2005), Fe concentration in soil solution which causes toxicity was highly vary in the range of 10 to $500 \mathrm{ppm}$. The study results from Majerus et al. (2007) and Mehraban et al. (2008) showed that $\mathrm{Fe}$ concentration in nutrients solution with magnitude of 250 to $500 \mathrm{ppm}$ and $\mathrm{pH}$ of 4.5 to 6.0 had significantly increased $\mathrm{Fe}$ concentration in plant tissues and showed $\mathrm{Fe}$ toxicity symptoms for sensitive plants. The study results from Dorlodot et al. (2005) which used $\mathrm{Fe}$ 
concentration in nutrients solution with magnitude > $250 \mathrm{ppm}$ showed Fe toxicity symptoms and decrease of crop growth. The effort to decrease iron concentration can be done by improvement of water management system in order to facilitate leaching process on land. Results of study by Imanudin and Armanto (2012) showed that improvement of micro water management at tidal lowland swamp was capable to decrease iron concentration from $78.68 \mathrm{ppm}$ to $41.31 \mathrm{ppm}$

Table 3. Laboraory results of water quality after field treatment

\begin{tabular}{lrrrr}
\hline \multirow{1}{*}{ Samples } & \multicolumn{4}{c}{ Parameters } \\
\cline { 2 - 5 } & $\mathrm{pH}$ & $\mathrm{Fe}(\mathrm{mg} / \mathrm{L})$ & $\begin{array}{c}\text { Sulphate } \\
(\mathrm{mg} / \mathrm{L})\end{array}$ & \multicolumn{1}{c}{$\begin{array}{c}\text { Salinity } \\
(\mathrm{mg} / \mathrm{L})\end{array}$} \\
\hline Tertiary channel & & & & 0.2 \\
water & 2.95 & 4.01 & 29.98 & 0.06 \\
Box water & 3.7 & 0.32 & 6.84 & 0.06
\end{tabular}

Salinity condition (Table 3) in DecemberJanuary was very low in tertiary channel $(0.2$ ppm) and even close to zero in quarterly channel $(0.06 \mathrm{ppm})$. This condition was due to high rainfall and high tide water from secondary channel that was incapable to enter because water gate was in totally closed operation. Water management at this area was not only to retain water, but also to protect water in tertiary channel from salt water intrusion during dry season.

The effect of salinity on plant growth had been extensively studied. The study by Alsaeedi, et al., (2018) showed that cucumber germination percentage up to $5,000 \mathrm{ppm}$ salinity was not significantly different than that of control treatment $(0$ ppm). The decrease of germination percentage was started at 7,500 $\mathrm{ppm}$. On the other hand, germination percentage at 4,000 ppm salinity condition showed significant decrease for chilly crop.

Study results by Asih et al. (2015) on mustard crop showed that addition of $\mathrm{NaCl}$ salt at 2,000 ppm had no significant effect on all values of growth parameters. The growth parameter values became significantly different at 4,000 ppm concentration. This condition was also in accordance to study results by Utama et al. (2009) for rice crop.
Treatment at salinity concentration of 4,000 ppm had significant effect on growth disturbance. The study results by Mansour et al. (2005) showed that corn seeds treated with $150 \mathrm{mmol} \mathrm{NaCl}$ for 15 days had caused significant decrease in term of fresh produce weight and dry weight of roots as well as crown weight of corn.

\section{Effect of Water Gate Operation}

Results of field study showed that water flow system at tertiary and secondary levels had produced balance water flow, i.e. no flow was occurred when water surface on tertiary channel was $86 \mathrm{~cm}$ and water surface on secondary channel was $192 \mathrm{~cm}$. This condition was occurred at wet season in December 2016. Figure 12 showed that hourly water surface condition in tertiary channel was at constant level in 20 December 2016, although water surface on secondary channel was dropped. This condition was developed because water gate was closed (goose neck pipe was installed) by farmers during crop growth period so that no outflow of rainfall water. This system was applied thoroghly for rice cultivation at tidal swamp land of C typhology (Imanudin et al., 2015). 


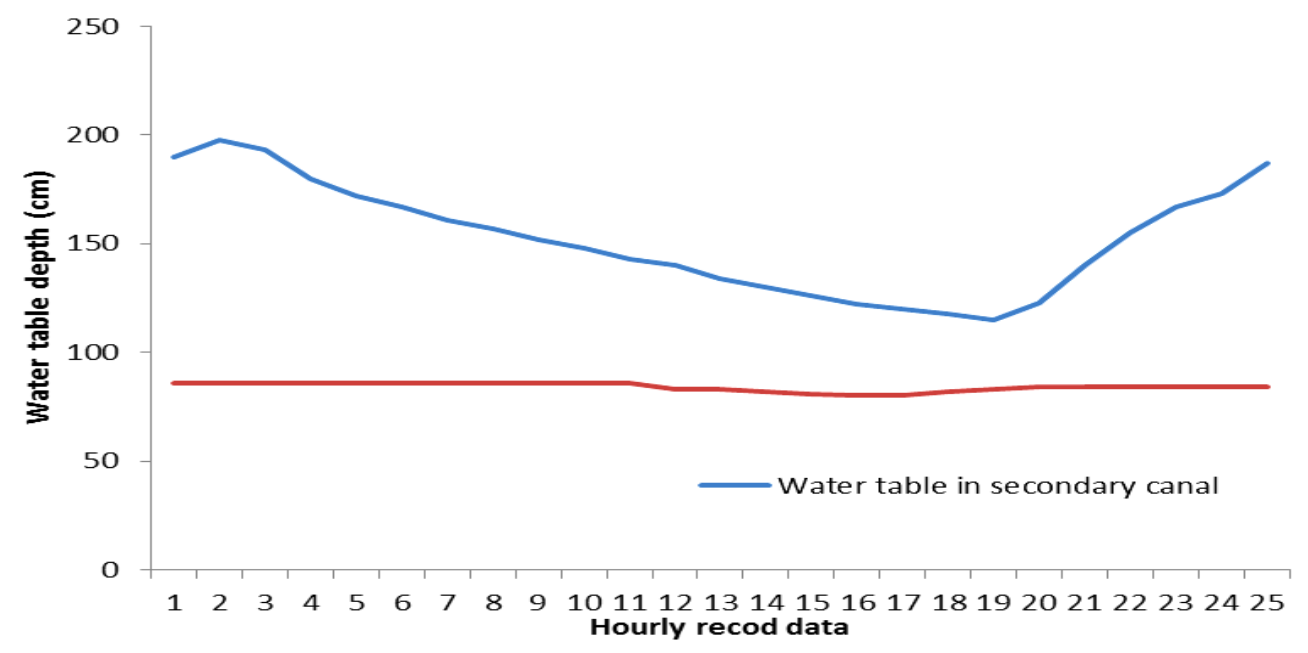

Figure 12. Water table dynamics in tertiary and secondary channels

The main objective of water management at B typhology land in which high tide water can not flow into land and secondary channel had very poor water quality so that high tide water was not allowed to flow into tertiary channel was to maximize rainfall water utilization. Therefore, water gate in tertiary channel should be closed (goose neck pipe was installed) so that rainfal water can be retained and tertiary channel was filled with rainfall water.

Planting period for rice crop was in the middle of October up to early of December, whereas harvest was started from the middle of February. Operation activity of water gate was in 8 December 2016 in which goose neck pipe was installed by farmers to retain water. Results of water table observation at this period showed that land was flooded with water at thickness of $15 \mathrm{~cm}$ and water $\mathrm{pH}$ of 5. Rice growth condition can be seen in Figure 13. Water table surface had increased as a results of water retention operation (Figure 14). This showed that rainfall water was capable to increase water table or there was no surface flow (zero runoff). This condition was produced due to tertiary channel condition that full of water.
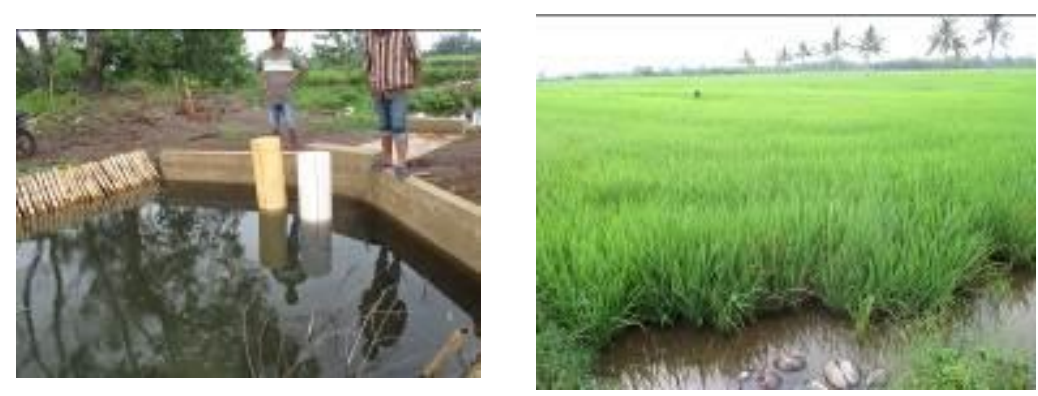

Figure 13. Operation condition of water gate and rice crop growth (18 December 2016)

Farmers effort to close water gate was conducted during growth period of rice crop, especially at vegetative phase. Closed operation of water gate had caused water in tertiary channel was at maximum level of 80$90 \mathrm{~cm}$ which capable to continously increase of water table condition at land plot (zero runoff). Since the start of rainfall occurrence in the middle of October, water table was continously increased close to soil surface, whereas flooding was occurred starting from November and water flooding with thickness 
of 10 to $15 \mathrm{~cm}$ was occurred in January (Figure 19). Farmers try to drop water level in the middle of January because rice crop was approaching late generative phase (approaching harvest). However, because insufficient duration of low tide water and rainfall water was relatively high, then water surface in tertiary channel was always full and no significant change of water table drawdown at paddy field plot. Evapotranspiration requirement for rice crop was in the range of 3.6 to $4.1 \mathrm{~mm} /$ day (Hasibuan, 2010). Water table observation showed that crop water requirement can be fulfilled by rainfall water supply and there was occurrence of water excess (surplus).

Rice was harvested in 10-19 February. Rice growth condition can be seen in Figure 20. Water in land was in flooded condition with thickness range of 15 to $20 \mathrm{~cm}$ from soil surface. Harvest was started from the middle of January up to the end of February. Rice production was still low with magnitude of 3 ton/ha although it was higher than that of previous year with magnitude of 2.5 ton/ha. Improvement of crop variety should also be done in order to increase crop production. Impara variety was more suitable to be cultivated at flooded land condition. According to Djufry (2015), rice crop of 1-6 Impara group had adaptation capability on flooded environment. Tolerance capability toward water flooding was in the range of 7 to 14 days at vegetative phase and higher rice productivity was in the range of 4 to 6 ton/ha of milled dry rice. Moreover, Gribaldi et al. (2014) had added that Impara 5 variety had better adaptation on flooding environment condition. This variety contains gen $S u b-1$ having relatively higher content of chlorophyl, carbohydrate and dry weight. Maximum water depth at the study area was in the range of 20 to $25 \mathrm{~cm}$ so that rice crop was never totally flooded at vegetative phase.

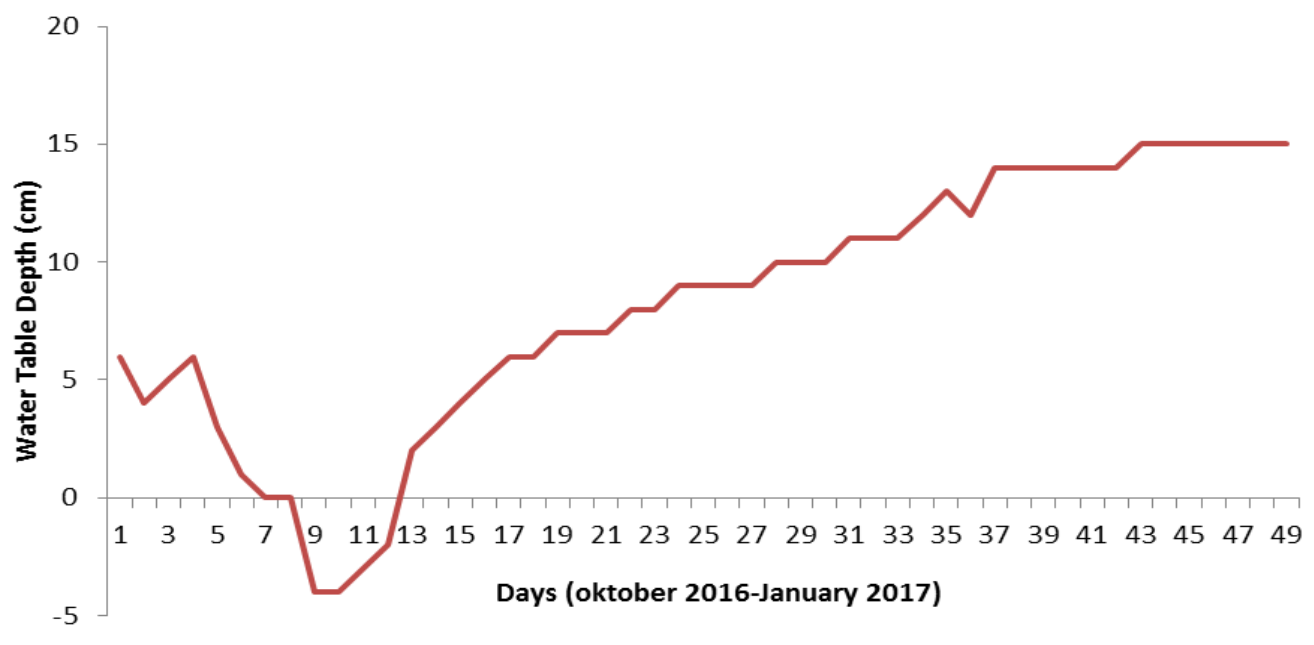

Figure 14. Water table dynamics at land plot as affected by water gate operation

Condition of excess water volume (which cause flooding) is frequently results in aeration stress, whereas insufficient water volume results in dryness stress. For rain fed rice, crop will experience decrease in growth and production if available water condition is less than field capacity level (Ahmed et al.,2014). Water should always available at field capacity condition (Supriyanto, 2013), whereas water should available above field capacity zone for maximum production of paddy field rice. The study by Fonteh et al. (2013) had showed that continues flooding treatment had showed no significant effect than that of intermitten irrigation. Continues irrigation (continues flooding with water 
depth of $3 \mathrm{~cm}$ ) had produced the same rice yield than that of intermitten irrigation (Hossain et al., 2016).. Moreover, Naharia et al. (2005) added that continues flooding treatment with height of $5 \mathrm{~cm}$ gave yield of 5 ton/ha. It was reported in Iran (Pascual and Wang, 2016) that water application depth of 3 to $7 \mathrm{~cm}$ at irrigation area could produced rice yield of 8.0 ton/ha. Therefore, water table control at paddy field plot with maximum depth of 5 to $10 \mathrm{~cm}$ was very important to produce maximum rice yield at swamp area.

In addition to water quality improvement and water table control, production increase should also followed by ameliorant substances addition in soil coupled with biofertilizer addition (Panhwar et al., 2016).

\section{Acknowledgements}

The authors gratefully acknowledge to the provision of financial support ref. 184.2/PL.040/H.1/09/2016 dated 13-092016 from Agricultural Research and Development Agency Ministry of Agriculture Republic Indonesia.

\section{CONCLUSION AND RECOMMENDATION}

\section{Conclusions}

- $\quad$ Low productivity at the study area was due to high level of soil and water acidities, phyrite oxidation process during dry season and acid substances were not maximally leached due to low perfomance of drainage network. Micro network at tertiary plot was unavailable and tertiary channel was still connected to secondary channel in one direction.

- $\quad$ The study of land use showed that rice cultivation was still very potential because land use for rice crop was 83 $\%$ and the rest of $17 \%$ was for other usage, including plantation.

- Improvement of water quality at the study area can be done by using passive technology through improvement of biological process in

Journal of Wetlands Environmental Management

Vol 6, No 2 (2018) 93 - 111

http://dx.doi.org/10.20527/jwem.v6i2.165 channel base or water body. Ameliorant substances were used to increase $\mathrm{pH}$ of water. Proper substances after laboratory test were rice straw ash, coconut fiber, compost and soil from below of banana trees. These substances were capable to increase $\mathrm{pH}$ of water from 2 to 5 .

Conblock construction using mixture of sand-cement-lime-rice sraw ash with volume ratio of $(2: 2: 1: 3)$ showed significant effect in increasing $\mathrm{pH}$ of water. Testing on channel water with 1:4 volume ratio of concblock and water could increased $\mathrm{pH}$ of water up to 8 .

All ameliorant substances were generally capable to increase $\mathrm{pH}$ value, to decrease iron concentration, but not all were capable to decrease sulphate concentration.

Tertiary channel improvement was conducted by constructing water gate of goose neck type so that rainfall water can be maximally retained in tertiary channel and high tide water from secondary channel having poor water quality could not enter into tertiary channel. Water gate opening was done when water rainfall was in excess quantity or height of goose neck pipe can be regulated up to water maximum level above the highest water table height.

Water gate was operated at opened mode for initial period of wet season up to planting season (free water inflow and outflow) to accelerate leaching. Water gate was operated as rainfall water retention up to January and was opened at approaching harvest period (February-March).

The study results of water qualty improvement in the field showed that there was significant change of water quality between tertiary channel and quarterly channel. Water in quarterly channel had already showed the quality which fulfill good irrigation water 
standard. The observed indicators were consisted of sulphate concentration, iron concentration and salinity. $\mathrm{pH}$ of water in the field was relatively good with magnitude of 5 , but laboratory test showed $\mathrm{pH}$ value of 3 . This discrepancy was due to microbia activities during the time span of laboratory test.

\section{Recommendations}

The study results and activities evaluation showed that water control by using water retention system at first planting season was effective and capable to develop land condition which was similar as found at irrigation paddy field area. Therefore, it was recommended to policy makers that water gate type for tidal swamp land of $C$ typhology was goose neck-type. Construction was conducted at secondary embankment which requires permanent construction from concrete. The strength of this construction should be based on load burdened by road that was used as transportation lane with magnitude of at least 10 tons.

Further study is needed to investigate the impact from the changes of water quality and soil quality. Therefore, monitoring at dry season is required to determine network perfomance and effectiness of ameliorant substances in increasing $\mathrm{pH}$ of soil. The current study can only be done at wet season. It should be continued to determine the impact during dry season and all at once to introduce other crops cultivation except rice.

he passive water treatment should be developed by addition of sulphate reducing bacteria. This was due to the fact that application of ameliorant substances and phytoremediation could only capable to increase $\mathrm{pH}$ of water and to decrease iron concentration, but incapable to decrease sulphate concentration.

\section{REFERENCES}

Alsaeedi A, El-Ramady H, Alshaal T, ElGarawani M, Elhawat N, and Al-Otaibi A. 2018. Exogenous nanosilica improves germination and growth of cucumber by maintaining $\mathrm{K}^{+} / \mathrm{Na}^{+}$ratio under elevated $\mathrm{Na}^{+}$stress. Plant Physiol Biochem Journal 125:164-171. doi: 10.1016/j.plaphy.2018.02.006. Epub 2018 Feb 9.

Asih, E.D, Mukarlina, Irwan Lovadi. 2015.

Tolerance of mustard green plants

(Brassica juncea L. against $\mathrm{NaCl}$ Salt

Salinity Stress. Journal Protobiont. 4 (1): 203-208

Ahmed, R., Bari, N., Haque, M. and Rahman, M. 2014. Effect of Herbicide Dose and Water Management on Weed Control Efficiency and Yield Performance of Boro Rice. Journal of Science Foundation, 12(2):39-46

Djufry, F. and Kasim, A. 2015. Adaptability Test on New High Yielding Varieties of Swamp Rice Planted on Newly Opened Paddy Field in The District of Merauke Province of Papua. J. Agrotan 1(1): 99109

Food Security Agency of Indonesia (FSA). 2017, Produksi Beras tahun 2017. http://bkp.pertanian.go.id/berita-398produksi-beras-2017-ditarget-77-jutaton.html

Fonteh, M.F, Tabi, F.O., Wariba, A.M, and Zie, J. 2013. Effective Water Management Practices in Irrigated Rice to Ensure Food Security and Mitigate Climate Change in a Tropical Climate. Agric. Biol. J. N. Am., 2013, 4(3): 284290

Gribaldi, Suwignyo, R.A., Hasmeda, M. and Hayati, R. 2014. Fertilization Effect on 
Morphophysiological Change of Two Rice Varieties at Flooding Stress Condition. J. Agron. Indonesia 42 (1): 17 $-23$

Hossain., M.B. 2016. Effect of Alternate Wetting and Drying Versus Continuous Flooding on Carbon Rates in Rice and Soil. Int. J. Agril. Res. Innov. \& $\mathrm{T}_{\mathbf{1}} 109$ (1): 26-33

Hasibuan, S.H. 2010. Analysis of Irrigation Water Requirement at Paddy Field Irrigation Area of Kampar District. Journal of APTEK 3(1):97-102.

Imanudin, M. S., Bakri., Karimuddin, Y. 2017. Maksimalisasi Panen Hujan untuk Penyediaan Air Bersih pada Budidaya Padi MT1 (November-Februari) di Lahan Pasang Surut Tipologi B/C Daerah Sugihan Kanan. Makalah disampaikan pada disampaikan pada Seminar Nasional Lahan Suboptimal Oktober 2017.

Imanudin, M.S. and Susanto, R.H. 2015. Intensive Agriculture of Peat Land Areas to Reduce Carbon Emission and Fire Preventation (A Case Study in Tanjung Jabung Timur Tidal Lowland Reclamation Jambi). Proceeding The $1^{\text {st }}$ Young Scientist International Conference of Water Resources Development and Environmental Protection, Malang, Indonesia, 5-7 June 2015.

Imanudin, M.S. and Bakri. 2014. Corn Cultivation Study during Wet Season at Reclaimed Area of Tidal Lowland in Effort to Develop 300\% Planting Index. Proceeding of INACID National Seminar, 16-17 May 2014, Palembang-South Sumatra. ISBN 978-602-70580-0-2.

Imanudin, M.S. and M.E. Armanto. 2012. Effect of Water Management Improvement on Soil Nutrient Content, Iron and Aluminum Solubility at Tidal Lowland Area. APCBEE Procedia 4
(2012): 253-258. (SCOPUS, Google Scholar and DOAJ indexes). Weblink:www.sciencedirect.com/science/.../S2 212670812002138

Imanudin, M.S., M.E. Armanto and R.H. Susanto. 2011. Developing Seasonal Operation for Water Table Management in Tidal Lowland Reclamations Areas at South Sumatra Indonesia. Journal of Tropical Soils, Unila Vol. 16(3):233-244

Imanudin, M.S., M.E. Armanto, R.H. Susanto and S.M. Bernas. 2010. Water Status Evaluation on Tertiary Block for Developing Land Use Pattern and Water Management Strategies in Acid Sulphate Soil of Saleh Tidal Lowland Reclamation Areas of South Sumatra. Journal of Agriculturas Science - AGRIVITA Vol 32(3): 241-253. ISSN 0126-0537. Weblink:

http://www.agrivita.ub.ac.id/index.php/ag rivita/article/view/16

Imanudin, M.S. and Armanto, M. 2012. Effect of Water Management Improvement on Soil Nutrient Content, Iron and Aluminum Solubility at Tidal Low Land Area. Available online at www.sciencedirect.com.

APCBEE Procedia 4 (2012) 253 - 258.

Kima, A. S., Chung, G.W., and Wang Y.M. 2014. Improving Irrigated Lowland Rice Water Use Efficiency under Saturated Soil Culture for Adoption in Tropical Climate Conditions. Water 2014, 6, 28302846; doi:10.3390/w6092830

LWMTL. 2006. Program of Land and Water Management of Tidal Lowlands (LWMTL) at Banyuasin District, South Sumatra Province. June 2004-August 2006.

Meijide, A., Gruening, Goded, Seufert, G. 2017. Water Management Reduces Greenhouse Gas Emissions in a Mediterranean Rice Paddy Field. 
Agriculture, Ecosystems Environment. 238(1): 168-178

Mercau, L.G., Nosetto, D.M., Bert, F., Gimenez, R. and Jobbagy, G.E. 2016. Shallow groundwater dynamics in the Pampas: Climate, Landscape and Crop Choice Effects. Agricultural Water Management. 163( 1): 159-168.

Mansour MMF, Salama KHA, Ali FZM, Abou Hadid AF. 2005. Cell and Plant Repsonses to $\mathrm{NaCl}$ in Zea mays $\mathrm{L}$. Cultivars Differing in Salt Tolerance. Gen. Appl. Plant Physiol. 31(1-2): 29-41

Moore, J.W. 1991. Inorganic Contaminant of Surface Water Springer Verlag, New York.

Naharia, O., Saeni, S.M., Sabihan, S and Burhan, H. 2005. Irigation Techn 110 and Soil Tillage at Paddy Field Rice Cultivation for Methane Gas Mitigation (CH4). Biological News 7(4)

Nugroho, K., Suping, S. and Sarwani, M. 1993. Land Characteristics in Reclamation Research and Acid Sulphate Soil Tillage. Collaboration between Soil and Agroclimate Resarch Center and P3N Project, Jakarta. 1-15

Pascual, J.V. and Wang, Y.M. 2016. Impact of Water Management on Rice Varieties, Yield, and Water Productivity under the System of Rice Intensification in Southern Taiwan. Water 2017, 9, 3; doi:10.3390/w9010003.

Panhwar, A.Q., Naher, A.U., Shamshuddin, J. Radziah, O. and Hakeem, R.K. 2016. Management of Acid Sulfate Soils for Sustainable Rice Cultivation in Malaysia. Soil Science: Agricultural and Environmental Prospectives. pp 91-104
Sebastian, A. and Prasad, M.N.V. 2015. Trace Element Management in Rice. Agronomy 5(3) 374-404; doi:10.3390/agronomy5030374

Supriyanto, B. 2013. The Effect of Drieness Stress on Growth and Yield of Local Dry Land Rice of Jambu Cultivar. (Orysa sativa Linn). Jurnal Agrifor 12(1): 77-82.

Suriadikarta, D.A. and Sutriadi, M.T. 2007. Types of Potential Land for Agricultural Development at Swamp Area. Journal of Agricultural Research and Development. No. 36(3): 115-122

Sebastian, A. and Prasad, M.N.V. 2015. Trace Element Management in Rice. Agronomy 2015, 5(3): 374-404; doi:10.3390/agronomy5030374

Susanto, R.H. 2007. Manajemen Rawa Terpadu untuk Pembangunan Berkelanjutan. Prosiding Kongres Ilmu Pengetahuan Wilayah Indonesia Bagian Barat. Unsri-LIPI. Palembang Juni 2007

Scofield, F.E, 1936. The Salinity of Irrigation Water. Smith Ann. Rep. 1935: 275-283.

Utama, M.Z.H., W. Haryoko, R. Munir, Sunadi. 2009. Screening of rice varieties tolerant to salinity on swamp land, in Pesisir Selatan Regency. J. Agronomy Indonesia 37: 101-106

Zimmerman, I., Fleige, H. and Horn, R. 2017. Longtime Effects of Deep Groundwater Extraction Management on Water Table Levels in Surface Aquifers. Journal of Soil and Sediment.17(1):133-143

Yusuf, A. I. 2014. The Study of Irrigation Water Quality Criteria. Journal of Irrigation. 9(1): 1-15 